\title{
The Swiss Constitution and a weak-form unconstitutional amendment doctrine?
}

\author{
Rosalind Dixon* and Felix Uhlmann**
}

Direct democracy is a long-standing feature of the Swiss constitutional system, but it is increasingly being deployed in ways that threaten basic commitments to constitutional democracy in Switzerland. This article considers possible constitutional responses to this problem, and in particular whether there is scope for an unconstitutional amendment doctrine (UCA) to constrain the scope of popular initiatives in Switzerland. It suggests limited legal and political-cultural support for a substantive or "strong" UCA in Switzerland, given the tradition of relatively narrow and weak judicial review by the Swiss Supreme Court. At the same time, it argues for the plausibility of a weaker, more procedural version of the UCA doctrine, whereby the Court suspends the effect of a proposed initiative, and gives Parliament the final word on whether to give it affect via subsequent implementing legislation. While closely related to existing, procedural versions of the UCA doctrine, this version of the UCA doctrine is distinctive in its combination of judicial suspension and legislative implementation of a proposed amendment, or its connection to theories of weak form review. It also has an important connection to current European human rights law-based constraints on amendment in Switzerland: it draws on European and global standards as a basis for determining what constitutes a democratic minimum core in Switzerland, and further reinforces the status of those standards as an unamendable feature of the current Swiss constitutional order.

\section{Introduction}

The Swiss Constitution is globally renowned for its commitment to direct democracy. Citizens in Switzerland may challenge any new legal provision by way of popular referendum. Even more important, citizens may initiate a process of constitutional

* Professor of Law, UNSW Sydney. Email: rosalind.dixon@unsw.edu.au. The author thanks Melissa Vogt for outstanding research assistance.

** Chair of Constitutional and Administrative Law as well as Legislative Studies, University of Zurich. Email: felix.uhlmann@rwi.uzh.ch. The author thanks, lic. iur. Eva Scheifele, scientific assistant, for her valuable collaboration on this article. 
amendment - simply by gaining 100,000 signatures in support of a proposal. ${ }^{1}$ Since the first popular initiative in 1893, more than 400 initiatives have been proposed, covering a broad range of subjects. Some concern fundamental institutional questions such as the proportional representation election system of the Swiss National Council. ${ }^{2}$ Other initiatives target particular issues such as the prohibition of absinthe, ${ }^{3}$ highway speed limits, ${ }^{4}$ and the protection of bear, wolf, and lynx. ${ }^{5}$

In recent years, however, there has been a marked turn toward initiatives with a more troubling character. ${ }^{6}$ In 2009, for instance, the initiative process led to amendments making it illegal to build a minaret in Switzerland. ${ }^{7}$ In 2010, the Swiss Constitution was amended to require the expulsion of foreign nationals convicted of certain crimes, ${ }^{8}$ and in 2014, to impose quotas on the number of foreigners admitted to the country. ${ }^{9}$ Most of these initiatives faced sturdy resistance in Parliament and from the media. Still, they were accepted by a majority of citizens voting and by a majority of states. ${ }^{10}$ This has also led to debate in Switzerland, and elsewhere, as to whether the Swiss Constitution itself provides any means of limiting the effect of current or future amendments of this kind. ${ }^{11}$

Some limits clearly exist. In particular, constitutional revisions must not violate mandatory provisions of international law. ${ }^{12}$ But these limits are under pressure in two ways: they do not cover the full range of basic structural as well as rights-based constitutional commitments potentially under threat via the referendum process, and likely they cannot prevent passage of amendments that target the status of international law in the Swiss system. The question this invites, is whether there are potentially other, more implied limitations on such a power-such as those imposed by the doctrine of unconstitutional constitutional amendment (UCA).

The doctrine of UCA is one of the most important developments in comparative constitutional law in the last several decades, and it has been applied by courts in numerous countries to limit attempts to use constitutional amendment procedures

1 Fed. Const. Swiss Confederation [hereinafter Const.], Apr. 18, 1999, SR 101, arts. 138, 139, 140, 141, 141a; see, e.g., T. Fleiner, A. Misic, \& N. Töpperwien, Constitutional Law in Switzerland qף 115-154 (2012); P. Egli, Introduction to Swiss Constitutional LaW 67-75 (2016).

2 A. Kley, Demokratie, in StaAtsRecht § 3 [64] (2d ed., G. Biaggini, T. Gächter, \& R. Kiener eds., 2015),; A. Kölz, Geschichtliche Grundlagen, in Verfassungsrecht § 7, ๆ 36 (D. Thürer, J.-F. Aubert, \& J. P. Müller eds., 2001).

3 Adopted by popular vote in 1908, BBl [Federal Gazette] IV 572 [1908].

4 Rejected by popular vote in 1989, BBl I 250 [1989].

5 Failed due to insufficient signatures in 2013, BBl 427 [2014].

6 J. P. Müller \& G. Biaggini, Die Verfassungsidee angesichts der Gefahr eines Demokratieabsolutismus, 116 ZBL [Schweizerisches Zentralblatt für StaAts- und Verwaltungsrecht] 235, 243ff. (2015).

7 Compare Const. art. 72 [3], BBl 3437 [2010]; AS [chronological collection of federal law] 2161 [2010].

8 Const. art. 121, q甲 [3]-[6], BBl 2771 [2011]; AS 1199 [2011]; see, e.g., W. Haller, The Swiss Constitution in a Comparative Context $\uparrow \uparrow$ 587-596 (2d ed., 2016).

9 Const. arts. 121, 121a, 197 no. 9, BBl 4117 [2014], AS 1391 [2014].

10 See, e.g., G. Müller \& F. Uhlmann, Elemente einer Rechtssetzungslehre (3d ed., 2013), § 10, 9434.

11 Y. Hangartner \& A. Kley, Die demokratischen Rechte in Bund und Kantonen der Schweizerischen Eidgenossenschaft §10, ๆๆ 474-487 (2000); T. Gächter, Rechtsetzung, in STAATSREсHT § 23, ๆף 77-82 (2d ed., G. Biaggini, T. Gächter, \& R. Kiener eds., 2015); P. Tschannen, StaAtsrecht der Schweizerischen Eidgenossenschaft $§ 44$, $\mathbf{q \uparrow}$ 27-30 (4th ed., 2016).

12 Const. arts. 193[4], 194[2]. 
to infringe basic human rights, or reshape the basic constitutional democratic order. ${ }^{13}$ Yet, in its "strongest" form, the doctrine also seems to have little chance of successful application to the Swiss case: the Swiss Constitution imposes explicit limits on the Swiss Supreme Court's (SSC's) power to engage in any strong form of judicial review. Article 190 provides that the SSC may not invalidate federal legislation for inconsistency with other parts of the Constitution. ${ }^{14}$ The SSC's power to engage in even ordinary forms of review thus depends on its capacity to rely on the enforcement of international law, and particularly the European Convention on Human Rights (ECHR). It thus seems extremely unlikely that the Court would attempt, or, if it did, be effective in attempting, to exercise the kind of super-strong powers of review necessary to impose absolute substantive limits on popular processes of constitutional amendment. The decision on such reviews lies traditionally within Parliament that may invalidate popular initiatives violating mandatory provisions of international law. ${ }^{15}$

The question the article considers is whether the SSC could adopt a weaker, more procedural form of UCA doctrine, which seeks to empower the Swiss Parliament to impose similar restraints on the current trend toward revisionary popular amendment. The Swiss Parliament has express power to disallow certain amendments, and the Court has found that not all amendments are necessarily "self-executing." This idea of non-self-executing amendments, we suggest, also creates a distinct possibility of a procedural — or weak-form - model of UCA: it allows the SSC to deprive initiatives of immediate legal effect, and leave to Parliament the question of whether to override such an order by passing relevant implementing legislation. We further suggest that the SSC should use such a power in a way modeled on the UCA doctrine: it should find that initiatives are not self-executing wherever they have the effect of altering the basic democratic structure, or "democratic minimum core," of the Swiss Constitution. In doing so, the SSC could also help buttress the effectiveness of limits on the amendment process arising from international law-by ensuring that both rights and structural constitutional provisions are protected from repeal by way of initiative, and especially those structural provisions that themselves enshrine Switzerland's commitment to international (or European) law.

Determining the content of such a democratic minimum core is obviously a difficult one, and one that raises the dangers that courts may overreach in applying the notion of a non-self-executing initiative. There are, however, at least two potential answers to these concerns: first, the very fact that we are proposing a weak-form UCA doctrine

13 Y. Roznai, Unconstitutional Constitutional Amendments: The Migration and Success of a Constitutional Idea, 61 Ам. J. Comp. L. 657 (2013).

14 A. Epiney, Das Verhältnis von Völkerrecht und Landesrecht aus der Sicht des Bundesgerichts, in JusLETTER OF March 18, 2013, 125 ff. [hereinafter Epiney, Jusletter]; A. Epiney, in Bundesverfassung, Basler Kommentar [Basel Commentary on the Federal Constitution of 1999], art. 190 1-19 (B. Waldmann, E. M. Belser, \& A. Epiney eds., 2015) [hereinafter Epiney, Basel Comm. Const.]; HaLler, supra note 8, qף 551-566; Tschannen, supra note $11, \S 9$, 1 甲 27-35.

15 Const. art. 139[3]. 
means it is clearly open to the Swiss Parliament to override a court decision in reliance on the democratic minimum core, simply by passage of ordinary legislation. Second, we suggest courts can look to broader European or global practices as a useful guide for determining the democratic minimum core's content. We illustrate this by reference to recent Swiss experience: this form of "transnational anchoring," we suggest, would point to the appropriateness of applying a weak-form UCA doctrine in the context of initiatives involving automatic deportation, and minarets, but not necessarily other initiatives, such as those involving the treatment of sex offenders.

\section{Constitutional amendments in Switzerland}

Constitutional amendments, under the Swiss Constitution, may be requested by the people or decreed by the Federal Assembly. ${ }^{16}$ They may have the form of a general proposal or a specific draft of the provisions proposed. ${ }^{17} \mathrm{~A}$ specific draft requires only one popular vote to become constitutional law and mitigation through parliamentary drafting is excluded. Hence, initiatives are overwhelmingly submitted as specific drafts.

A proposal for a constitutional amendment is first submitted to the Federal Chancellery. It may be rejected only where the title is misleading, subject to a possible appeal to the SSC. The text of the proposed amendment will be published in the Federal Gazette, triggering the time limit of eighteen months to gather 100,000 signatures. ${ }^{18}$ This is a relatively undemanding requirement to meet: 100,000 signatures represent less than 2 percent of Swiss voters, and signature collecting is often led by wellorganized interest groups. ${ }^{19}$ Valid initiatives are then submitted to the Swiss Federal Council (executive branch), ${ }^{20}$ to be submitted to Parliament with recommendations (and possibly a counter proposal). Parliament is required to assess an initiative's validity within two and a half years. A valid initiative is then submitted to popular vote. To be adopted, a proposal must receive double majority support - that is, majority support both nationwide and from voters in a majority of cantons. ${ }^{21}$ This is, compared to other national constitutions, a relatively undemanding requirement: No quota for participation is required, and participation varies between 30 percent and 70 percent, most commonly in the area of 40 to 50 percent. $^{22}$

The prerequisites for adoption are identical for amendments from Parliament, as well as for partial and total revision of the Constitution. In the case of a counter proposal from Parliament, voters decide separately on both amendments, and in case

16 Const. art. $194[1]$.

7 Const. art. 139 [2].

8 Const. art. 139 [1].

19 G. Müller, Rechtssetzung und Staatsverträge, in Verfassungsrecht § 70, ๆ 10 (D. Thürer, J.-F. Aubert, \& J. P. Müller eds., 2001); EGLI, supra note 1, at 67-69.

20 Const. art. 97 [1]-[2], art. 105 [1] Parlg [Parliament Act] of Dec. 13, 2002, SR [classified compilation of federal law] 171.10.

21 Const. art. 195.

22 https://www.bfs.admin.ch/bfs/de/home/statistiken/politik/abstimmungen/stimmbeteiligung.html (last accessed on Jan. 31, 2018). 
both being adopted, voters are asked a tie-break question in the same ballot. ${ }^{23}$ Voting material is accompanied by governmental recommendations that must fairly include the arguments of the initiative's sponsors.

Popular initiatives have increasingly become a driving force in Swiss (constitutional) politics. Admittedly, not all initiatives are voted upon, and even fewer become constitutional law. From the 456 initiatives proposed before early 2018, only 209 were submitted to popular vote. The others failed to gather the necessary signatures (116) or were withdrawn (99). Four were invalidated; these initiatives will be analyzed in detail below. From the 209 initiatives submitted to popular vote, only 22 were finally adopted. A popular initiative thus has a roughly 5 percent chance of becoming constitutional law. ${ }^{24}$

Still, one cannot underestimate the political impact of popular initiatives. Since 2014, there have been nearly twenty successful proposals, compared to roughly the same number of amendments in the entire thirty-year period prior to 2014. Many of these changes have also gone to the heart of Switzerland's character as a constitutional democracy. Some initiatives have dealt with topics of relatively minor constitutional significance, targeting, for instance, "rip-off artists" ${ }^{25}$ and the ownership of second homes. ${ }^{26}$ Several of these initiatives, however, adopt a level of detail and prescriptive focus that comes close to displacing Parliament's role in ordinary democratic decision-making.

Other initiatives more directly threaten Switzerland's constitutional democratic character by seeking to restrict the scope of fundamental rights. One recent successful initiative, for instance, adopts a prohibition on the building of minarets (as part of a Mosque), in direct contradiction to Switzerland's long-standing commitment to the right to religious freedom.

Another seeks to provide for automatic deportation of non-citizens: in February 2016, for example, Swiss voters decided on an initiative designed to "enforce" the 2010 initiative on the expulsion of foreigners, ${ }^{27}$ which itself provided for automatic deportation of non-citizens convicted of serious crimes (such as murder, rape, drug dealing), or shown to have benefited from fraud for social security benefits. ${ }^{28}$ The sponsors of the later initiative considered that the 2010 constitutional amendment was watered down by Parliament, the Federal Council, and the courts, and thus the newer initiative consisted of a detailed list of crimes that if committed would immediately (some crimes, on recurrence) terminate any right of foreign persons to stay in Switzerland. ${ }^{29}$ Against initial support, the later initiative was

23 Const. art. 139b [2]; Müller \& Uhlmann, supra note 10, § 10, ๆ 433; U. Häfelin et AL., Schweizerisches BundesstaAtSREcht 1799 (9th ed., 2016).

24 https://www.admin.ch/ch/d/pore/vi/vis_2_2_5_9.html (last accessed on Jan. 31, 2018).

25 Const. art. 95 [3], art. 197 no. 8; BBl 299 [2009].

26 Const. art. 75 b, art. 197 no. 8; BBl 8757 [2008], 6623 [2012]; see, e.g., A. Griffel, Die Umsetzung der Zweitwohnungsinitiative - eine Zwischenbilanz, 115 ZBL 59 ff. (2014).

27 P. Übersax, Zur Zulässigkeit der Durchsetzungsinitiative-eine Einladung zur Reflexion, 115 ZBL 600 (2014); Y. Hangartner, Bundesgerichtlicher Positionsbezug zum Verhältnis von Bundesverfassung und Völkerrecht, AJP [Aktuelle Juristische Praxis] (2013) 698, 703-707.

28 Swiss Vote for Deportation of Foreigners Who Commit Serious Crimes, The Guardian, Nov. 29, 2010, http:// www.theguardian.com/world/2010/nov/28/swiss-vote-deportation-foreigners-crime (last accessed on Jan. 31, 2018).

29 BBl 9459 [2013], 2701 [2015]. 
rejected in February $2016^{30}$ (meaning that the somewhat milder implementation by Parliament entered into force).

Another, more recent initiative proposes that Swiss constitutional law should be treated as the supreme source of law in Switzerland, and that international treaties in conflict with constitutional law should be terminated. ${ }^{31}$ It is generally understood that this amendment may force Switzerland to leave the Council of Europe as it is hard to reconcile with the ECHR. The expulsion of criminal foreigners will remain a topic of popular initiatives; an initiative targeting only male offenders is currently under way. $^{32}$ Other quite radical proposals also continue to be debated: An initiative to reintroduce the death penalty for sex killing was withdrawn in 2012. ${ }^{33}$ Another proposed initiative stipulated discharge for civil servants including judges who are responsible for the temporary or early release of an offender if the offender commits a severe crime during his or her release. ${ }^{34}$ It did not attract sufficient signatures.

\section{Anti-democratic amendments and UCA doctrine}

In many democracies, over the last few decades, constitutional amendment procedures have also been used in ways that pose a similar threat to substantive commitments to democracy - or that involve the threat of "abusive" constitutional action, or formal reliance on democratic constitutional procedures, in order to undermine the substance of democracy from the inside. ${ }^{35}$ Faced with this problem, both courts and constitutional designers have also sought to come up with an important "check" against this danger (i.e., a doctrine of unconstitutional constitutional amendments).

\subsection{The UCA doctrine in comparative perspective}

In some countries, the text of the constitution explicitly provides that certain provisions of the constitution are "unamendable," or not open to alteration by way of ordinary constitutional amendment. In Germany, for example, the Basic Law contains an "eternity clause," which protects both federalism-based principles and the guarantees of fundamental rights in articles 1-20 of the constitutional amendment. Article 89 of the French Constitution provides that the "republican form of government shall not be the object of an amendment"; and article 139 of the Italian Constitution provides that the "form of Republic shall not be a matter for constitutional amendment." Eternity clauses are also found, in various forms, in the constitutions of Cameroon, the Central African Republic, Chad, the Congo, the Dominican Republic, East Timor,

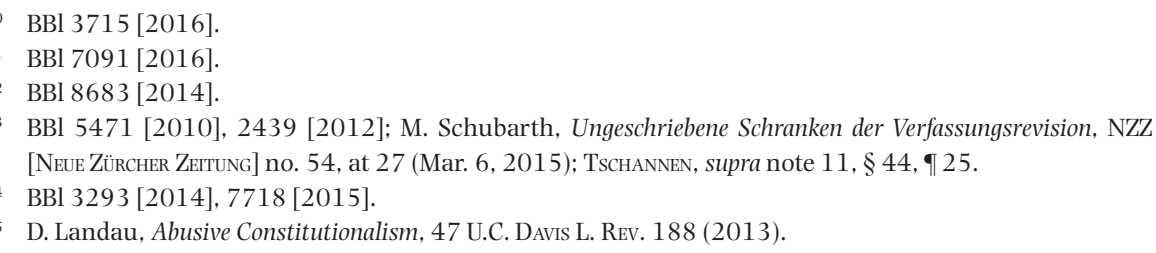


EL Salvador, Gabon, Guatemala, Honduras, Mauritania, Moldova, Namibia, the Republic of Guinea, Romania, Senegal, Tunisia, and the Ukraine. ${ }^{36}$

In several countries, courts have also identified various implied limitations on the power of constitutional amendment. In India, for instance, in the Golaknath case, the Supreme Court of India (SCI) initially held that all constitutional amendments could be subject to broad-ranging judicial review - as "laws" subject to review for consistency with the existing Constitution. ${ }^{37}$ In Kesavanada, in 1972, the SCI partially retreated from that position, and held that the power to amend the Constitution was not subject to ordinary review of this kind. ${ }^{38}$ But in doing so, a majority of the Court also held that the power of amendment was subject to additional, implied limitations relating to the "basic structure" of the Constitution: the power of amendment, a majority of the Court held, could not be used to destroy or alter the basic structure of the existing Constitution. Similarly, in Colombia in the First and Second Re-election cases, ${ }^{39}$ the Constitutional Court held that the power to amend the Constitution was subject to similar implied limitations-i.e., could not be used wholly to replace the Constitution, or to create "a substitution" of the previous constitution.

Whether express or implied, a UCA doctrine of this kind cannot necessarily prevent dominant political actors from achieving anti-democratic forms of constitutional change. With sufficient political support, dominant political actors can always attempt to circumvent limitations of this kind via a process of actual constitutional replacement. Absent exceptional circumstances, courts will generally have limited power to check processes of replacement of this kind. ${ }^{40}$ But they can go a significant way to slowing down-or deterring — various forms of anti-democratic change. In many contexts, additional delays or hurdles of this kind can also allow for processes of social, economic, or political change, which themselves create an effective obstacle to relevant forms of change.

Indeed, in prior work one of us has shown (together with David Landau) how in Colombia, in the Second Re-election Case, the use of the substitution doctrine arguably had exactly this function. It created an additional speed bump on the consolidation of executive power in the hands of the president, which allowed time for the development of a deeper, more institutionalized party structure, to support the diffusion of executive power. In Switzerland itself, one could also imagine that, if there was sufficient delay in the enactment or implementation of particular initiatives, political attitudes or conditions might change in a way that created similar hurdles to substantively antidemocratic forms of constitutional change.

A clear danger of such a doctrine, however, is that in creating a tool to restrain antidemocratic constitutional change, it also gives courts the potential power to frustrate

36 For discussion of this, and other examples, of eternity clauses see, e.g., Richard Albert, The Expressive Function of Constitutional Amendment Rules, 59 McGill Law Journal 225 (2013); Richard Albert, The Structure of Constitutional Amendment Rules, 49 Wake Forest Law Review 913 (2014); Rosalind Dixon \& David Landau, Tiered Constitutional Design, 86 George Washington Law Review (Forthcoming, 2018).

37 IC Golaknath v. State of Punjab, 1967 A.I.R. 1643.

38 Kesavananda Bharati v. State of Kerala, (1973) 4 SSC 225.

39 Case C-1040/2005; Case C-141/2010.

40 See, e.g., D. Landau \& R. Dixon, Constraining Constitutional Change, 50 WAKe Forest L. Rev. 859 (2015). 
more democratic forms of change. The doctrine itself gives courts a form of "superstrong" power of judicial review in respect of all constitutional amendments. Thus, if courts over-enforce such a doctrine from a democratic standpoint, the doctrine itself may end up creating a form of "ultimate counter-majoritarian difficulty"-i.e., a situation in which courts simply end up protecting their own interpretation of constitutional norms, at the expense of broadly shared democratic understandings. This is also one reason why some comparative constitutional scholars may pause before embracing such a doctrine as part of the democratic constitutional "canon"; and why others suggest that, in most cases, it will be desirable to focus on creating procedural rather than substantive limits to processes of constitutional amendment. ${ }^{41}$

\subsection{Limits on a super-strong UCA doctrine in Switzerland}

In Switzerland in particular, the text, history, and structure of the Constitution also provide limited support for a super-strong form UCA doctrine of this kind. Unlike the German Basic Law, the Swiss Constitution contains no express eternity clause, or prohibition against certain kinds of constitutional amendment if not violating mandatory provisions of international law.

Swiss scholar Zaccaria Giacometti-a close relative to the famous artist Albertosought to identify "eternal" norms of the Swiss Constitution as early as 1949, in his influential treatise on Swiss constitutional law. ${ }^{42}$ Giacometti conceded that there were no peremptory constitutional norms on the face of the 1848 Constitution, but that such norms may be deduced from the Constitution as a whole. This argument, however, was not widely accepted: Jean-François Aubert, another influential scholar and later member of the Swiss Parliament, clearly took the opposite view in $1967 .^{43}$ Following the revision to the Swiss Constitution in 1999, Swiss scholars are also even more reluctant to acknowledge "unwritten" barriers to constitutional amendments. ${ }^{44}$

The Swiss Supreme Court also enjoys only quite weak, limited powers of judicial review: it generally lacks even ordinary powers of strong form review, let alone the kind of tradition of judicial review that would successfully support the judicial assertion of a super-strong power of judicial review, in the mold of the Indian "basic structure" or Colombian "substitution" doctrine.

The Court, under the 1848 Swiss Constitution, was given only quite limited jurisdiction: essentially, it settled civil law disputes — understood in a broad sense - among states and between the states and the confederation, ${ }^{45}$ and a few penal matters of high importance. ${ }^{46}$ It protected fundamental rights only if these cases were referred

41 See, e.g., V. Jackson, Unconstitutional Constitutional Amendments: A Window into Constitutional Theory and Transnational Constitutionalism, in Demokratie-Perspektiven:Festschrift für Brun-Otto Bryde zum 70. Geburtstag 47 (Bäuerle et al. eds., 2013).

42 F. Fleiner \& Z. Giacometti, SchWeizerisches BundesstaAtsRecht 705-707 (1949).

43 J.-F. Aubert, Bundesstaatsrecht der Schweiz (German ed. of 1967) 9 328 (1991/1995).

44 Hangartner \& KLey, supra note 11, § 10, ๆ 474 ff., ๆ 483 ff.; Tschannen, supra note 11, § 44, ๆ 27 ff., ๆ 29 ff.; M. Schefer \& A. Zimmermann, Materielle Schranken der Verfassungsgebung, 3 LeGes [MitTeiLungSBLATT DER Schweizerischen Gesellschaft für Gesetzgebung und Schweizerische Evaluationsgeseldschaft] 343 ff. (2011).

45 Const. art. 101.

46 Const. arts 103-104. 
to it from Parliament. ${ }^{47}$ The powers of the SSC were considerably enlarged in 1874 , notably to protect fundamental rights. ${ }^{48}$ Still, the Constitution clearly stated that laws from Parliament and international treaties were binding on the SSC, ${ }^{49}$ which may be also explained by the fact that threats to fundamental rights were expected from cantonal law, less from federal laws. The exemption of federal laws from full constitutional review was transposed into the Constitution of 1999. Articles 148 and 190 thus currently read as follows: Parliament is the "supreme authority of the Confederation," subject only "to the rights of the People and the Cantons" and "The Federal Supreme Court and the other judicial authorities [shall] apply the federal acts and international law." These provisions are also widely understood in Switzerland to mean that courts must apply federal laws, even where they find that these laws violate the Swiss Constitution.

This does not mean that the SSC lacks any and all powers of judicial review. The SSC has always understood article 190 of the Swiss Constitution and its predecessors as a duty to apply federal laws, but not as a prohibition to review. ${ }^{50}$ The Court will scrutinize federal legislation for consistency with the Constitution if it finds that such review is "justified." In the course of such review, the Court may also decide that a federal law contradicts the Constitution and thus-in the Court's own words- "invite" Parliament to amend that law, ${ }^{51}$ or seek to bring the law into conformity with the Constitution, via a process of statutory interpretation. ${ }^{52}$

In addition, the SSC will not apply federal law if it infringes the ECHR or any other self-executing provision in an international treaty. ${ }^{53}$ This practice is justified by the fact that article 190 of the Swiss Constitution names federal laws and international treaties as sources that must both be applied by the Court - i.e., both are immune from invalidation through judicial review and must be applied. ${ }^{54}$ In this way, the ECHR has also become a form of "surrogate constitution," in many cases, allowing full judicial review on federal laws. In 2012, the SSC also expressly affirmed the idea that this gives the Court power not to apply constitutional amendments that are directly inconsistent with the ECHR. ${ }^{55}$ In November 2015, the Court confirmed and extended this practice, holding that the new constitutional provisions imposing quotas on the number of foreigners admitted to the country ${ }^{56}$ could not restrict the freedom of movement

47 Const. art. 105.

48 Const. art. 113 [1] no. 3; W. Kälin, Verfassungsgerichtsbarkeit, in VerfassungsRecht § 74, qף 2-3 (D. Thürer, J.-F. Aubert, \& J. P. Müller eds., 2001); Epiney, Basel Comm. Const., supra note 14, art. 190, 1.

49 Const. arts 113 [3], $114^{\text {bis }}[3]$.

50 Haller, supra note 8, ๆ 563; Epiney, Basel Comm. Const., supra note 14, art. 190, 35.

51 E.g., BGE 140 I 305, 310 [5]; Epiney, BASEL Comm. Const., supra note 14, art. 190, 36; Tschannen, supra note $11, \S 8, \boldsymbol{q} 10$.

52 Tschannen, supra note $11, \S 9$, 1 甲 $38-39$.

53 BGE 139 I 16, 28 f., ๆ甲 5.1-5.2.

54 Epiney, Basel Comm. Const., supra note 14, art. 190, 21, art. 5, 82.

55 BGE 139 I 16, 26 f. [4.3.3]; Epiney, JusLETTER, supra note 14, ๆ 25 ff.; Hangartner, supra note 27; L. Gonin, Les initiatives sur le renvoi des étrangers criminels - simple balade sur les rives du droit pénal ou plongée éprouvante dans les profondeurs de la mer constitutionnelle?, in JAHRBuch FÜr MigRATIONSReCht 37, 49 ff. (A. Achermann et al. eds., 2013/2014).

56 See supra note 9. 
guaranteed by the bilateral treaties between Switzerland and the EU-even though the new constitutional provisions clearly targeted exactly these treaties. ${ }^{57}$

Still, it is important to bear in mind that the ECHR and other international treaties do not cover all areas of constitutional law. ${ }^{58}$ The ECHR, on its face, protects only various human rights-based commitments under the Constitution, not broader structural constitutional guarantees - such as those relating to the separation of powers, or rule of law. European Union law (which is not directly applicable as Switzerland is not a member country of the EU) gives somewhat broader protection to these requirements, but also imposes limited requirements in terms of basic structural constitutional arrangements. ${ }^{59}$

There is also clearly still important historical skepticism, in Switzerland, of judicial review in general, and in particular the judicial resolution of highly charged political controversies. ${ }^{60}$ For a significant period, the federal government, and in some cases even Parliament, continued to enjoy adjudicatory powers over cases originating in the states, even after the establishment of the SSC. State constitutions are also still reviewed and guaranteed through the Federal Assembly, ${ }^{61}$ in effect barring judicial review by the SSC of all state-based constitutional challenges. ${ }^{62}$ It is also telling that disputes between the federation and the states are rarely brought before the SSC although state rights are quite extensively provided for by the Constitution.

It is thus extremely unlikely that Swiss legal-political culture would be receptive to the existing substantive version of the UCA doctrine, which effectively gives courts super-strong powers of judicial review with respect to all breaches of basic democratic constitutional commitments. Even the decisions of the SSC, in 2012 and 2015 , emphasizing the supremacy of the ECHR over the amendment process have met with significant controversy among legal scholars, and in the media. ${ }^{63}$ This controversy is also arguably one reason why, more recently, initiatives have been proposed with the aim of re-asserting the supremacy of the Swiss Constitution over the ECHR.

57 BGE 142 II 35, 38 ff., ๆๆ 3.2-3.3; G. Biaggini, Die "Immerhin liesse sich erwägen”-Erwägung im Urteil 2C_716/2014: über ein problematisches höchstrichterliches obiter dictum, 117 ZBL 169 (2016); M. Oesch, Kommentar zum Urteil des Bundesgerichts, II. öffentlich-rechtliche Abteilung, vom 26. November 2015, 2C_716/2014, 117 ZBL 197 (2016); see also A. Epiney, Auslegung und Verhältnis des Freizügigkeitsabkommens zum nationalen Recht, in JusLETTER OF NOVEMBER 26, 2015.

58 R. Baumann, Die Umsetzung völkerrechtswidriger Volksinitiativen, 111 ZBL, 241, 249 (2010).

59 See, e.g., A. von Bogdandy, Founding Principles, in Principles of European Constitutional Law 11 (2 ed., A. von Bogdandy \& J. Blast eds., 2009); T. Altwicker, "Convention Rights as Minimum Constitutional Guarantees? The Conflict Between Domestic Constitutional Law and the European Convention on Human Rights," in Constitutional Crisis in the European Constitutional Area: Theory, Law and Politics in Hungary and Romania 331 (A. von Bogdandy \& P. Sonnevend eds., 2015).

60 HaLler, supra note 8, ๆๆ 608-609; Fleiner, Misic, \& TöpperwiEn, supra note 1, ๆ 666.

61 Const. art. 51 [2], art. 172 [2].

62 EGLI, supra note 1, at 44.

63 See note 56 supra; H. Keller \& N. Balazs-Hegedüs, Paradigmenwechsel im Verhältnis von Völkerrecht und Landesrecht?, AJP 712 (2016); Hangartner, supra note 27; A. R. Ziegler \& K. Odendahl, Die SCHwEIZERIsche Bundesverfassung, St. Galler Kommentar [St. Gall Commentary on the Federal Constitution of 1999], Einleitung zum Kommentar, Bundesverfassung und Völkerrecht, ๆๆ 53-56; see also Interviews with the SSC judges Zünd and Seiler, in NZZ (Nov. 2 and Nov. 28, 2013), and Der Volkswille spielt keine Rolle, in NZZ (Jan. 30, 2016). 


\subsection{Constitutional text, culture, and a legislative UCA doctrine?}

Similarly, there is limited textual and historical support in Switzerland for a purely legislative or parliamentary form of UCA doctrine, designed to protect the basic structure of Swiss Constitution democracy. Parliament, under the Swiss Constitution, is required to assess the validity of proposed initiatives. ${ }^{64}$ Article 139(3) of the Swiss Constitution of 1999 provides for the following grounds: "If the initiative fails to comply with the requirements of consistency of form, and of subject matter, or if it infringes mandatory provisions of international law, the Federal Assembly shall declare it to be invalid in whole or in part." But it also clear, from the terms of article 139, that this gives Parliament very narrow power to find a proposed amendment invalid based on substantive scope. There are no constitutional safeguards that amendments do not abolish the separation of powers, federalism or fundamental rights if the latter do not fall into the category of mandatory provisions of international law. ${ }^{65}$

If one turns to practice, it is apparent that Parliament is reluctant to invalidate a popular initiative. ${ }^{66}$ From the beginnings in 1893 - an initiative prohibiting kosher butchering, allegedly to protect animals but with some unpleasant anti-Jewish undertones $^{67}$ - until 2016, more than 300 initiatives reached the quorum of necessary signatures. Only four were invalidated. If Parliament invalidated an initiative, it never invoked "eternal" constitutional norms but preferred technical and narrow reasons.

In 1955, Parliament considered an initiative to reduce military spending by half for the year 1955 (or 1956 the latest) as unfeasible. ${ }^{68}$ It later let pass an initiative proposing the abolishment of the Swiss army, ${ }^{69}$ and initiatives preventing the acquisition of military airplanes. ${ }^{70}$ One may reasonably assume that the initiative from 1955 would have survived parliamentary scrutiny if better drafted, although Parliament was clearly hostile to this initiative in the midst of the cold war.

Two initiatives were struck down because they violated the single-subject requirement. In 1974, an initiative against inflation and increase in prices proposed substantial state intervention ${ }^{71}$ - it would have been also conceivable to invalidate the initiative on the grounds that it lead to total revision of the Swiss Constitution, hence requiring a more burdensome procedure. The other initiative proposed the transfer of military expenditures to social security; it was invalidated in $1995 .{ }^{72}$ One may justly ask whether Parliament lacks coherence in its practice on the single-subject requirement as other initiatives were certainly also questionable under the standard of the 1995 invalidation. Disregarding coherence, one may contend that Parliament is

64 Egli, supra note 1, at 69-70; Fleiner, Misic, \& TöPperwien, supra note 1, ๆๆ 127-128.

65 R. Kiener \& M. Krüsi, Bedeutungswandel des Rechtsstaates und Folgen für die (direkte) Demokratie am Beispiel völkerrechtswidriger Volksinitiativen, 110 ZBL 237, 247 (2009).

66 Gächter, supra note $11, \S 23, \Upsilon 982$.

67 BBl IV 401 [1893].

68 BBl II 1463 [1955]; A. Kley, Die Umsetzung von Volksinitiativen aus politisch-historischer Sicht, 3 LEGES 497, 506 (2015).

$69 \mathrm{BBl} 8954$ [1999].

70 BBl III 1555 [1992].

71 BBI III 919 [1977].

72 BBl III 570 [1995]. 
disinclined to invalidate initiatives. There is the (unspoken) doctrine that in case of doubt, one should let pass the initiative. The SSC, which reviews similar question from the cantons, has taken a stricter view on the single-subject requirement. The restraint of Parliament can be shown also by another comparison: Parliament has repeatedly allowed initiatives that were clearly retroactive. ${ }^{73}$ They would have been struck down by the SSC if scrutinized as cantonal law.

The fourth initiative that was invalidated has been mentioned before. It concerned the automatic deportation of foreigners who entered Switzerland illegally. ${ }^{74}$ It is interesting that Parliament nullified the initiative on the narrowest possible grounds-i.e., for violation of mandatory international law - but not because of a conflict with international law in general. Indeed, the "simple" violation of international law including the ECHR is not a ground for invalidation. The sweeping prohibition to build minarets is hardly in compliance with the ECHR but made it into the Swiss Constitution. ${ }^{75}$

\section{Toward a weak-form UCA doctrine}

We suggest, however, that there is in fact adequate legal-cultural support in Switzerland for the development of a more hybrid, procedural form of judicial-legislative UCA doctrine-i.e., one that combines the powers of both the SSC and Parliament to create a form of weak-form UCA doctrine.

\subsection{A weak-form UCA doctrine?}

The idea of weak-form review is one that has gained increasing interest and attention in comparative constitutional law scholarship in recent years. First identified by Mark Tushnet, it is the idea that judicial review may be relatively broad and robust in scope but ultimately subject to equally broad override by legislatures - exercising ordinary legislative powers, or similar special powers of override subject to ordinary majority voting requirements. ${ }^{76}$ Judicial review of this kind aims to promote more vibrant responsive democracy, by helping counter relevant blockages in the political process. ${ }^{77}$ But equally, as Stephen Gardbaum has noted, it aims to answer democracy-based objections to stronger forms of judicial review, by allowing scope for majority-based decision-making procedures to play a role in the resolution of constitutional questions open to reasonable disagreement. ${ }^{78}$

73 E.g., BBl 6459, 6461 f. [2011], 2267 [2013]; BBI IV 254, 259 [1991]; MüLLER \& UhLMANN, supra note 10, § 10, \436; Tschannen, supra note 11, § 44, 28; E. Grisel, Les droits poulaires au niveau fédéral, in Verfassungsrecht $§ 24, \uparrow 26$ (D. Thürer, J.-F. Aubert, \& J. P. Müller eds., 2001).

74 BBl 1355 [1996].

75 J.-P. Müller, Wie wird sich das Bundesgericht mit dem Minarettverbot der BV auseinandersetzen?, JUSLETTER OF MARCH 1, 2010. It can hardly be defended as mere construction regulation as it clearly targets a religious minority (Ch. Winzeler, BASEL Comm. CONST. art. 72, 5759).

76 M. Tushnet, Weak Courts, Strong Rights: Judicial Review and Social Welfare Rights in Comparative Constitutional Law (2009).

77 R. Dixon, Responsive Judicial Review (2016) (unpublished manuscript).

78 S. Gardbaum, What's So Weak About “Weak-form” Review? A Reply to Aileen Kavanagh, 13 Int'L J. Const. L. 1040 (2015). 
A weak form of UCA doctrine also offers the potential to achieve a similar compromise between the dangers of a purely political and judicial model of supervising the process of constitutional amendment. Compared to a purely political model, a weak-form UCA doctrine empowers courts to play an important role in helping check the danger of abusive constitutional change-or constitutional change that threatens the substantive commitment to constitutional democracy within a polity. ${ }^{79}$ Like a stronger-form UCA doctrine, a weak-form doctrine can increase the political costs, or simply time and opportunity costs, for proponents of enacting certain kinds of antidemocratic constitutional change. It can also help slow down the process of anti-democratic change, thereby giving greater time for broader social and political conditions to shift away from support for the proposed change, or for opponents to the change further to mobilize their opposition.

But equally, compared to a traditional, strong-form UCA doctrine, a weak-form doctrine gives a democratically elected Parliament (and possibly voters) a much greater role in deciding what kinds of amendment count as pro- versus anti-democratic in nature. By doing so, a doctrine of this kind can also play an important role in helping guard against the danger of judicial overreach, under a traditional strong-form UCA doctrine. By giving Parliament the authority to displace a judicial decision to block a constitutional amendment, a weak-form UCA clearly helps alleviate any sense of an "ultimate counter majoritarian difficulty"-i.e., it allows democratic legislative majorities to play a key role in determining the ultimate contours of constitutional change. ${ }^{80}$ A weak form of UCA will also be less likely to cause political backlashes against courts.

Indeed, it shares many of the same virtues in this context as existing, procedural understanding of the UCA doctrine, which emphasizes the value to courts requiring different levels of democratic support for amendments affecting the basic structure of the constitution. As Vicki Jackson notes, the virtue of a procedural UCA doctrine in this context is that it does not wholly prevent democratic actors from achieving certain forms of change: it simply requires that, to do so, they must engage in sufficiently deliberative and inclusive processes of decision-making, and gain appropriately high levels of popular support, which correspond to the seriousness of the proposed changes. ${ }^{81}$ A weak-form UCA doctrine is also ultimately a close relative of purely procedural limits on the amendment process: it allows clear scope for particular amendments to be given future effect, via a further act of Parliament. The difference is simply that, compared to some purely procedural versions of the doctrine, it adopts criteria that are thoroughly substantive in nature-i.e., uses openly substantive understandings of the "minimum core" of a democratic constitution in deciding what kinds of amendment should be subject to the requirements of additional parliamentary approval.

Of course, for such a doctrine to work, certain quite special conditions will need to be met: first, the Parliament itself cannot be the body proposing a relevant

79 Landau, supra note 35.

80 Compare Jackson, supra note 40 (arguing that procedural versions of an UCA raise fewer legitimacy concerns than more substantive versions).

81 Id. at 60-62. 
amendment, or have unilateral power to propose and approve amendments, because if so, Parliament will have the power to almost entirely defeat the effect of a court decision, simply by repassing a proposed amendment. Put another way, if constitutional amendments can be unilaterally proposed and ratified by Parliament, a weak-form UCA will tend to be simply equivalent to a common form of double passage requirement for proposed amendments. Second, for such a doctrine to work, the Parliament in a particular country must have a history of at least partial independence from the executive or other political movements and elites. In many countries facing the threat of abusive constitutionalism, or anti-democratic constitutional change, there will also simply be an insufficient tradition of legislative independence, or strength, of this kind.

Where such conditions are satisfied, however, it is quite possible that Parliamentsor a particular faction of legislators within a Parliament - may work with a court to deprive anti-democratic amendments of ultimate legal effect.

\subsection{A weak-form UCA in Switzerland?}

We also believe that, historically at least, legal and political conditions in Switzerland have met the requirements for the success of a weak-form UCA doctrine. Parliament in Switzerland has a role in assessing the "validity" of initiative proposals; this does not amount to a substantive requirement that Parliament approves the substance of proposed initiatives. Further, there is a long tradition of strong and robust legislative constitutionalism in Switzerland, and indeed of Parliament itself serving as an important counterweight in debates over proposed constitutional amendments by way of initiative. Indeed, over the course of Swiss history, roughly a quarter of all initiatives have been withdrawn and quite often this has been due to a counterproposal offered by either the Federal Council or Parliament, which sought to modify a proposed amendment or pass legislation endorsing some but not all of the relevant propositions. ${ }^{82}$ For a long time, one could in fact safely assume that an initiative facing a counterproposal from Parliament had little chance of acceptance. Some exceptions confirmed the rule: in 1982, voters accepted an initiative to prevent abuses in price maintenance over a direct counterproposal. ${ }^{83}$ And, in recent years, the weight of Parliament counterproposals has also been put in question. But the long tradition of legislative independence and success in locking certain proposed amendments by initiative nonetheless remains.

There is also some precedent, in recent Swiss experience, for the SSC applying exactly this kind of weak-form UCA doctrine-via a doctrine finding that certain amendments, by virtue of their nature and terms, are not self-executing, or require further legislative implementation to be further effective. In 2012, the SSC decided upon the legal effects of the initiative on automatic deportation of criminal foreigners. ${ }^{84}$ The case concerned a young Macedonian drug dealer, who had spent most of his life in Switzerland. The SSC held, first, that in the circumstances an expulsion

82 HANGARTNER \& KLEY, supra note 11, § 16, ๆ甲 896-899.

83 BBl I 858 [1982]; BBl I 928 [1983].

84 BGE 139 I 16; see also supra notes 52 and 54. 
order was disproportionate, for the purposes of article 8(2) of the ECHR. The Court then proceeded to consider whether a new constitutional provision, inserted via the initiative process, could nonetheless require the Court to order that the deportation should proceed. In answering that question, the Court also emphasized that the relevant amendment should be understood in its wider constitutional context, or according to a general constitutional commitment to "practical concordance" (praktische Konkordanz) among constitutional norms. The court further held that in order for this requirement to be met in the circumstances, the relevant provisions required "fine-tuning" (erforderliche Feinabstimmung) by the Parliament. Otherwise, there was a danger that there would not be the necessary degree of concordance among constitutional norms (as well as with international law). ${ }^{85}$ This also means that unless and until the necessary legislation was passed by the Parliament, the amendment itself could have no direct legal application. ${ }^{86}$

The response of the Parliament on automatic deportation was to adopt legislation providing for deportation in the case of serious crimes, but equally giving courts discretion not to order deportation in "exceptional circumstances" or based on clear "hardship," given a noncitizen's ties to the Swiss community. ${ }^{87}$ While seriously narrowing judicial discretion, in this context, the relevant legislation thus goes an important way to reinstating core constitutional democratic commitments to the rule of law (i.e., judicial supervision of deportation) and norms of proportionality in punishment. In many ways, the proposal also effectively enforces a prior counterproposal from the Parliament, prior to the passage of the amendment, which would have proposed giving courts discretion in the making of orders for deportation.

The example shows not only that SSC and Parliament apply a weak UCA doctrinewithout explicitly referring to it - but also that the doctrine can be implemented without constitutional or legislative changes.

\subsection{Dangers and limits}

There are, of course, potential limits to such a doctrine. At a formal level, it depends on the idea that there is some role for Parliament to play in "implementing" an amendment to achieve consistency with other legal norms. If the drafters of an initiative adopt quite specific language, which purports to be self-executing, this may thus itself make it difficult for the SSC to apply such a doctrine: the SSC already tested the limits of interpretation in its deportation case in 2012, and might be forced to stretch the notion of necessary fine-tuning even further if declaring other amendments

85 The Court in this context emphasized the paramountcy of the ECHR over all law, including constitutional amendments. See also H. Koller, Wunsch und Wirklichkeit im Umgang mit Volksinitiativen—Methodik der Umsetzung anhand von drei Beispielen, 3 LeGes 545 ff. (2015).

86 BGE 139 I 16, 26 f., ๆศ 4.2-4.3; P. Tschannen, Mehr Volk, weniger Staat: Direkt anwendbare Verfassungsinitiativen im Bund, in Festschrift für Peter Hänni zum 65. Geburtstag 131 (E. M. Belser \& B. Waldmann eds., 2015).

87 D. Sarkar, Switzerland: Referendum on Deportation of Convicted Foreigners, Mar. 2016, http://www. australianetworknews.com/switzerland-referendum-deportation-convicted-foreigners/ (last accessed on Jan. 31, 2018). 
non-self-executing. ${ }^{88}$ One must also take into consideration that future drafters of initiatives will try to escape this doctrine by an even more specific language or by initiatives that target the very norms that cause the need of fine-tuning (e.g., the principle of proportionality). ${ }^{89}$

Because of its weak-form status, such a doctrine also cannot prevent the adoption of amendments that are ultimately supported by a national majority of legislators, or potentially even a clear majority of citizens. The response to the SSC's 2012 decision on the deportation of foreigners is a good example: many supporters of the 2010 initiative on this topic were extremely unhappy with the "compromise" reached by the SSC, and Parliament, in regard to deportation. They thus proposed a new initiative consisting of an even more specific list of crimes that, if committed, would immediately (some crimes on recurrence) terminate any right of foreign persons to stay in Switzerland. Legislation both by Parliament and the executive branch were superfluous if not excluded. Judicial review (in the cantons, with no recourse to the SSC) was limited to questions of deportation to a state in which torture or any other form of cruel or inhumane treatment or punishment was threatened. ${ }^{90}$ While the initiative was ultimately rejected, ${ }^{91}$ it also clearly highlighted the potential limits of a weak-form UCA doctrine: unless both the SSC and Parliament were willing to apply a weak-form UCA doctrine, for a second time, this could itself have defeated the effect of the SSC's 2012 decision, and Parliament's attempt to modify the worst aspects of the 2010 amendment. If a majority of Parliament supported such changes, this would itself also have been sufficient to defeat the effect of such a doctrine at an even earlier stage, following the SSC's 2012 decision.

If the SSC were to invoke such a doctrine too frequently, this might also provoke a backlash from voters, which could quickly lead to a weak-form UCA doctrine being defeated. Indeed, if initiatives are frequently frustrated via such a doctrine, this could lead voters to become willing to accept even more radical initiatives, which purport to have immediate legal effect notwithstanding fundamental constitutional principles or international law. ${ }^{92}$ The initiative on the pre-emption of national law over international obligations, for instance, could itself potentially be understood as a direct response to the SSC decisions in respect to the ECHR.

One important answer to this danger, however, is that the Court could attempt to apply a weak-form UCA doctrine in a way that is mindful of the danger of both judicial under- and over-enforcement of a basic commitment to constitutional democracy, or the kind of countermajoritarian difficulty associated with stronger forms of the UCA doctrine. One of us has shown, in prior work, with David Landau, how one way in which courts can potentially guard against the danger of under-enforcement in the application of a strong-form UCA doctrine is via consistent attention to transnational constitutional practices. ${ }^{93}$ If courts consider the constitutional practices of a large

88 B. Waldmann, Die Umsetzung von Volksinitiativen aus rechtlicher Sicht, 3 LeGes 521, 526 ff. (2015).

89 N. Raselli, Die Attacke auf das Verhältnismässigkeitsprinzip, AJP 1351ff. (2015).

90 BBl 9459 [2013], 2701 [2015].

91 BBl 3715 [2016].

92 Kiener \& Krüsi, supra note 64, at 252-254; Tschannen, supra note 11, § 41, ๆ 29a.

93 R. Dixon \& D. Landau, Transnational Constitutionalism and a Limited Doctrine of Unconstitutional Constitutional Amendment, 13 InT'L J. Const. L. 606 (2015). 
number of constitutional democracies, they may find that there is in fact broad support, or even something like an overlapping consensus, within such countries as to the importance of particular constitutional arrangements for democracy—or that particular constitutional norms are in fact part of something like a "democratic minimum core" found in almost all constitutional democracies. If domestic actors are seeking to detract from this minimum core, this would itself also provide an additional reason for the court to apply a UCA doctrine.

But conversely, if a court finds that many other democracies in fact operate without a particular constitutional norm, this may itself cast doubt on the fundamentality of such a norm to democracy, at a domestic level, and thus also on the desirability of interpreting an UCA to prevent change to such a norm: at the very least, it will require judges to articulate a compelling reason why such a provision is fundamental to the existing democracy constitutional order in a country, despite its consistent absence in constitutional democracies elsewhere. ${ }^{94}$ By linking the application of a UCA doctrine to this kind of process of comparison, or form of "transnational anchoring," courts can thus go a significant way toward guarding against the danger of both over- and under-enforcement of a UCA doctrine.

It is also clear that, applying such a standard, there are some recent initiatives in Switzerland that could legitimately attract the application of a weak-form UCA doctrine. There have, in recent years, been a range of laws passed by various constitutional democracies designed to limit the role of Islam in particular in the public sphere: a number of European countries have passed laws restricting the wearing of the headscarf, or other forms of Muslim dress. ${ }^{95}$ The SSC has protected exemption of swimming lessons in schools for Muslim girls some twenty years ago but reversed its decision in 2008. ${ }^{96}$ There have also been a number of de facto attempts, in constitutional democracies across the world, to modify or apply existing planning laws to effectively limit the building of mosques in particular areas. ${ }^{97}$ No other constitutional democracy, however, has passed a law entirely forbidding the construction

94

5 R. Nigro, The Margin of Appreciation Doctrine and the Case-Law of the European Court of Human Rights on the Islamic Veil, 11 Hum. Rts Rev. 531 (2010); R. McCrea, The Ban on the Veil and European Law, 13 Hum. RTs L. Rev. 57 (2013). For Switzerland, see BBl 9091 ff., 9109 ff. [2014], BGE 139 I 280; BGer, Dec. 11, 2015, 2C_121/2015.

96 BGE 119 Ia 178; BGE 135 I 79; BGer, 11 Apr. 2013, 2C_1079/2012; BGer, Mar. 7, 2012, 2C_666/2011 and EGMR, Jan. 10, 2017, no. 29086/12, Osmanoglu Aziz and Kocabas Sehabat v. Switzerland. See also Swiss Muslim Girls Must Take Swimming Classes with Boys: Europe Court (SBS News broadcast Jan. 11, 2017), https://www.sbs.com.au/news/swiss-muslim-girls-must-take-swimming-classes-with-boys-europe-court (last accessed on Jan. 31, 2018). It has, however, upheld a cantonal court decision that declared unconstitutional a prohibition of headscarves for students in public schools (BGE 142 I 49); see also A. Kühler \& F. Hafner, Schuldispensation zwischen Religionsfreiheit und "bürgerlichen Pflichten," AJP 913 (2011).

97 See, e.g., L. Goodstein, Across Nation, Mosque Projects Meet Opposition, N.Y. Times, Aug. 7, 2010, http:// www.nytimes.com/2010/08/08/us/08mosque.html (last accessed on Jan. 31, 2018); debate over a mosque in Bendigo, Australia: C. Stewart, How an Anti-Mosque Campaign in Bendigo Became a Battle Ground, The Australian, Sept. 26, 2015, http://www.theaustralian.com.au/life/weekend-australianmagazine/how-an-antimosque-campaign-in-bendigo-became-a-battle-ground/news-story/56ab194b1 371 acd5d1b97103a6286fd8 (last accessed on Jan. 31, 2018). 
of a mosque or minaret-as Anne Peters has noted, the 2009 Swiss initiative banning minarets was an entirely "novel constitutional provision" among constitutional democracies in Europe and more generally. ${ }^{98}$ It is fair to assume that the SSC, under its latest practice, would not apply the prohibition relying on both the ECHR and the need for further implementing legislation to be legally effective.

Of course, one of the important questions about a form of transnational anchoring of this kind in Switzerland is how it would relate to regional human rights norms (i.e., ECHR). ${ }^{99}$ For an amendment such as the anti-minaret amendment, the SSC would have clear power to disregard the amendment for inconsistency with the ECHR. While a number of states have entered reservations to the right to freedom of religion under the Convention, and the International Covenant on Civil and Political Rights (ICCPR), and thus deprived freedom of religion the status of a jus cogens norm (of the kind necessary, for example for the Swiss Parliament to disallow a proposed initiative in the first place), the ECHR gives broad protection to rights to freedom of religion (article 9), and non-discrimination (article 14). Depending on interpretation of articles 9 and 14 , this would likely provide a sufficient basis for the SSC to set aside the effect of such an amendment, even without relying on a weak-form UCA doctrine or an idea that an amendment is not self-executing.

Similarly, for proposals to require the automatic deportation of foreigners for certain crimes, there is clearly existing European law and practice that would give the SSC grounds for disregarding such an amendment, as inconsistent with binding international law. ${ }^{100}$ A proposal to remove all forms of judicial discretion to supervise the making of orders for deportation, or prevent deportation in cases where it is manifestly disproportionate and unjustified, might also be argued to contravene article 3 (preventing cruel, degrading, and inhuman treatment) or article 5 (requiring proper lawful procedures for ready deprivation of liberty and security of the person). ${ }^{101}$ For EU citizens, the SSC may also invoke the bilateral agreements. It has done so in respect to an amendment introducing quotas for immigrants to Switzerland. ${ }^{102}$

A UCA doctrine, however, is also in important ways somewhat broader than the protections found in the ECHR - it applies both to core civil and political rights in a democracy and to basic structural constitutional commitments, relating to the rule of law, the separation of powers, and free and fair elections. A commitment of this kind could also be extremely important to guarding against amendments that themselves target the current constitutional structure. Recall that one of the current proposed

98 A. Peters, The Swiss Referendum on the Prohibition of Minarets, EJIL: TALk!, Dec. 2, 2009, http://www.ejiltalk.org/the-swiss-referendum-on-the-prohibition-of-minarets/ (last accessed on Jan. 31, 2018).

99 Compare L. Garlicki \& Z. A. Garlicka, External Review of Constitutional Amendments? International Law as a Norm of Reference, 44 IsRael L. Rev. (2011) 343.

100 D. Thurnherr, in ST. Gall Comm. Const. art. 121, ๆ [38] (3d ed., B. Ehrenzeller \& B. Schindler et al. eds., 2014); A. Achermann, Basel Comm. Const. art. 121, ๆ [36].

101 J. Künzli \& W. Kälin, Das Verhältnismässigkeitsprinzip als Bestandteil des zwingenden Völkerrechts?, JusLETTER of June 23, 2014; A. Achermann, Basel Comm. Const. art. 121, 1 [36].

102 BGE 142 II 35, 39 f., ๆ 1 3.2-3.3; P. Uebersax, BASEl Comm. Const., art. 121a, ๆ [81]; R. J. Schweizer, ST. Gall Comm. Const. art. 121a, 1 [9ff.]; M. Oesch, Ein neues Fundament für die Europapolitik, NZZ No. 170, at 15 (July 23, 2015). 
initiatives in Switzerland is to amend the 1999 Swiss Constitution to provide that Swiss constitutional law should be treated as the supreme source of law in Switzerland, and that international treaties in conflict with constitutional law should be terminated. ${ }^{103}$ Articles 193(4) and 194(2) provide no check against the danger of anti-democratic amendments of this kind; and if such an amendment were passed, there would then be no clear check at all on other forms of abusive constitutional change.

A weak-form UCA doctrine, however, does not depend on the current language of these constitutional provisions; it depends on the idea that there are some basic features of the Swiss Constitution that are so core to its democratic constitutional status that they should be relied on by the SSC in determining what kinds of amendments can be considered self-executing, or rather call for further legislative implementation. The advantage of a democratic minimum core-based approach, in this context, is thus that it provides an important check against the danger of constitutional amendments designed directly to alter or challenge Switzerland international obligations - and its commitment to grounding Swiss law in the broader European constitutional project, or constitutional "block." 104

Even the very announcement of such a doctrine, by the Court, or scholars such as ourselves, may thus also serve as a valuable deterrent against the threat of proposals of this kind: by making clear that such proposals cannot in fact defeat the role of the SSC in protecting the minimum core of human rights (as, for example, in the minarets case), and structural guarantees of judicial independence and the rule of law and proportionality (in the case of the deportation of non-citizens), such a doctrine can also make it clear that there is limited political value to amendments designed to achieve this effect.

There is, of course, still an important question as to how regional versus global an approach the SSC should take, in seeking to give content to the notion of the democratic minimum core in Switzerland. We do not need to answer this question, for the purposes of argument in favor of connecting a weak-form UCA doctrine to transnational constitutional practices. It is sufficient, for our purposes, to note that the question is one that the SSC would need to address, at some point in the future, if it were to apply a doctrine broadly in line with our argument.

\section{Conclusion}

The unconstitutional amendment doctrine is one of the most important developments and indeed exports in comparative constitutional law in the last few decades. It is also an extremely important tool, or device, that can be used by both courts and the political opposition to protect core commitments to political democracy.

How the doctrine actually applies, and either succeeds or fails, however, will ultimately depend a great deal on the specific political context. Limits on constitutional amendment are only meaningful in a political context where there is some minimum

103 BBl 1965 [2015].

104 Compare M. E. Gongora Mera, Inter-American Judicial Constitutionalism 161 (2011). 
commitment to law, or legal constraint. If political elites are willing to ignore the constitution, and constitutional decisions of a court, the UCA doctrine will have no meaningful effect on constraining abusive constitutional change. Similarly, if political elites have the power and willingness to remove judges who enforce an UCA doctrine, or stack a court to encourage it to revisit and revise a prior decision enforcing the doctrine, the doctrine will have almost no effect.

Processes of constitutional amendment also ultimately operate in the shadow of processes and the potential for wholesale constitutional replacement. If political elites are willing to suspend a democratic constitution and impose military rule leading to a wholly new constitution, there is often no work that a UCA doctrine can do. Likewise, the effectiveness of the doctrine may also depend on the willingness of democratic voters to support proposals for wholesale constitutional replacement, as opposed to amendment. ${ }^{105}$

Attention to Europe, and the Swiss constitutional experience, also suggests another crucially important way in which the scope and success of the doctrine may depend on local legal and political conditions. ${ }^{106}$ Switzerland has long-standing commitments to constitutional democracy and the rule of law, which make it more likely that some form of UCA doctrine can succeed in constraining anti-democratic processes of constitutional change-such as those recently witnessed in the context of various proposed constitutional initiatives. But it also has a long-standing commitment to legislative constitutionalism, or limited judicial review, which makes it unlikely that the SSC could (and should) enforce a truly substantive or strong-form version of the UCA doctrine of the kind seen in countries such as Germany, India, or Colombia. For an UCA doctrine effectively to help constrain anti-democratic forms of constitutional change, in Switzerland, the article argues, it also needs to adapt to this distinctive aspect of Swiss legal-political culture-by seeking directly to harness both courts and legislatures in the enforcement of such a doctrine.

The idea of joint judicial-legislative enforcement of an UCA doctrine cannot work in all countries in all cases. But in cases where Parliament is not the sole author of constitutional amendments, and has a clear history of institutional independence, it is plausible to think that judicial-legislative cooperation of this kind could in fact work to limit the potential for more populist forms of anti-democratic constitutional change. By combining the role of courts and parliaments in determining what is and is not a threat to constitutional democracy, in this context, a weak-form UCA approach of this kind also clearly has important virtues compared to both purely political and judicial

105 Compare, e.g., Zimbabwe: C. Sabao \& M. Visser, Evaluating Authorial "Objectivity" and "Stancetaking" in Reporting the Making of a New Constitution in Zimbabwean Newspapers, 41 Communicatio 43 (2015); R. Southall, From Party Dominance to Competitive Authoritarianism? South Africa versus Zimbabwe, 10 Zeitschrift für Vergleichende Politikwissenschaft 99 (2016); and Venezuela, versus Ecuador in recent context: A. R. Brewer-Carias, The 1999 Venezuelan Constitution-Making Process as an Instrument for Framing the Development of an Authoritarian Political Regime, in Framing the State in Times of Transition: Case Studies in Constitution Making 505 (L. E. Miller ed., 2010); G. L. Negretto, Replacing and Amending Constitutions: The Logic of Constitutional Change in Latin America, 46 LaW \& Soc'y Rev. 749 (2012).

106 See also Hungary: Landau, supra note 35; Dixon \& Landau, supra note 92. 
models for controlling processes of constitutional amendment. It is, in this respect, a close relative of existing procedural understandings of the UCA doctrine, or versions of the doctrine that combine substantive and procedural elements. ${ }^{107}$

We further suggest that, as applied to a country such as Switzerland, there is relatively clear precedent for such a doctrine in the decisions of the SSC finding that certain initiatives are not self-executing, or require further legislation to be legally effective. There is also important guidance from European legal norms, and broader global practices, as to how the SSC might go about applying or anchoring such a doctrine.

Our hope, of course, is that there will not in fact be need for the SSC further to extend and test such a doctrine- - because mandatory international law will continue to impose limits on the process of amendment, and/or because the process of constitutional change by initiative has already reached its high-water mark, and there will be a return to more ordinary democratic politics in Switzerland in the near future. It may well be that the vote of February 2016 will become a turning point in hindsight. But we also fear that this may not be the case. The current signs are that the turn to direct democracy, or referendum-based politics, may well be spreading throughout Europe-not on the retreat in Switzerland, or elsewhere. ${ }^{108}$ There also continues to be a tension between the role of European and international law and the direction of constitutional amendments to come. The idea (or the phantom) of national sovereignty is likely to dominate politics in Switzerland - and elsewhere.

In the face of these trends, we suggest, a weak-form version of the UCA doctrine is also likely to be the most promising means by which various constitutional actors in Switzerland can help check, or at least, slow down these developments.

107 See Jackson, supra note 40; J. L. Colon-Rios, Beyond Parliamentary Sovereignty and Judicial Supremacy: The Doctrine of Implicit Limits to Constitutional Reform in Latin America, 44 Victoria U. Weldington L. Rev. 521 (2013); Carlos Bernal, Unconstitutional Constitutional Amendments in the Case Study of Colombia: An Analysis of the Justification and Meaning of the Constitutional Replacement Doctrine, 11 InT'L J. Const. L. 339 (2013); R. Albert, The Theory and Doctrine of Unconstitutional Constitutional Amendment in Canada, 41 QueEn's L.J. 143 (2016).

108 See, e.g., Brexit: E. Jones, Brexit's Lessons for Democracy, 58 Survival: Global Pol. \& Strategy 41 (2016); P. Singer, Direct Democracy and Brexit, Рвојест Syndicate, July 7, 2016, https://www.project-syndicate.org/ commentary/direct-democracy-and-brexit-by-peter-singer-2016-07 (last accessed on Jan. 31, 2018). 